\title{
REALITAS, FUNGSI DAN EKSISTENSI MEDIA SEBAGAI AKTOR POLITIK
}

\author{
Herianto \\ STKIP YAPTI Jeneponto \\ Muhammad Lutfi \\ Mahasiswa Program Studi Komunikasi Politik \\ Pascasarjana UNIFA
}

\begin{abstract}
Abstrak
Artikel ini berupaya menjelaskan realitas, fungsi dan eksistensi media dalam politik. Selain sebagai penyebar informasi atau berita, media juga dapat mempengaruhi dan mengintervensi proses politik di sebuah wilayah atau negara. Selain itu, artikel ini juga menguraikan berbagai produk media sebagai aktor politik seperti jurnalisme politik, proses editorialising dan akses pemrograman, penyiaran dan sebagainya. Produk media tersebut menegaskan bahwa posisi media dalam politik liberal sangat penting.
\end{abstract}

Kata Kunci: Media, Aktor Politik

\section{PENDAHULUAN}

Dalam dunia politik, media kerap disebut sebagai pilar keempat demokrasi selain eksekutif, yudikatif, dan legislatif. Brian McNair dalam bukunya An Introduction to Political Communication (2003:21) mencatat ada lima peran ideal media dalam mewujudkan kehidupan demokratis. Pertama, untuk menginformasikan apa yang sedang terjadi (surveillance). Kedua, media mengedukasi masyarakat inwal fakta yang ditemukan di lapangan. Pada posisi tersebut, McNair menggarisbawahi objektifitas jurnalis sebagai edukator. Soal fungsi untuk mendidik dan membentuk diskursus, John Allen Hendricks dan Robert E Denton sepakat dengan 
apa yang dikemukakan McNair. Menurut Hendricks dan Denton, media berperan membentuk, mengumpulkan, dan menyebarkan informasi agar masyarakat memahami isu politik dan memiliki keterikatan dengan politik.

Peda perkembangannya, peran media dalam panggung politik kontemporer semakin tak tergantikan. Fenomena yang muncul, media telah menjadi perpanjangan tangan dari aktor-aktor politik yang bermain. Perannya melampaui apa yang bisa dikerjakan oleh partai politik melalui cara-cara konvensional. Bisa dilihat dari bagaimana elite-elite politik mengeluarkan wacana dan gagasan-gagasannya melalui media. Pada tahap tertentu, media sendiri juga telah menjelma menjadi aktor politik.

Sebagai aktor politik, media bisa mengeluarkan atau menahan sebuah isu yang menguntungkan maupun merugikan aktor-aktor politik yang lain. Pembentukan opini publik terjadi, siapa yang memiliki akses atas media, dia yang menguasai opini. Tesis tersebut nampak pada pergulatan para elit politik dalam ajang Pemilihan Presiden (Pilpres) 2014 di Indonesia.

Media ramai merayakan gegap gempita pertarungan dua kandidat yang berlaga dalam gelaran Pilpres 2014. Hiruk pikuk tersebut melampaui garis batas antara pemilik media, aktivitas politiknya, dan ruang redaksi. Peniadaan batas terlihat dalam kebijakan redaksional. Produk media dari berita, editorial, sampai iklan politik menjadi kanal menyalurkan ideologi pemilik dan jurnalisnya. Hal itu muncul di sejumlah media massa di Indonesia, baik cetak mapun elektronik. Kenyataan tersebut menjadi bukti 
menarik untuk selanjutnya dikaji. Dalam hal ini, posisi dan struktur media dalam memainkan perannya sebagai 'aktor politik'.

\section{PERS DAN REALITAS POLITIK}

Kita mulai di tingkat yang paling umum, bahwa media aktif dalam mendefinisikan politik 'realitas'. Melalui proses pengumpulan berita dan produksi dijelaskan dalam bab sebelumnya, penonton akhirnya disajikan dengan 'selesai' artikulasi apa 'Benar-benar' hal-hal dalam urusan politik pada waktu tertentu. Wartawan berkomunikasi kepada kita 'arti' politik (Gerstle et al., 1991).

Mereka memasukkan peristiwa kehidupan politik ke dalam kerangka kerja narasi yang memungkinkan mereka untuk dikatakan sebagai berita. kerangka kerja ini melakukan tidak semi sepenuhnya terbentuk dari pena jurnalistik, tentu saja, tapi mengembangkan dari waktu ke waktu dalam interaksi dan kompetisi antara media berita yang berbeda, dan antara berbagai aktor dalam, atau sumber dari, cerita. Seiring waktu, kerangka bersaing yang dipersempit dan dihilangkan sampai satu kerangka yang dominan tetap. Meskipun selalu tunduk untuk menantang dan revisi, kerangka dominan, setelah dibentuk, menyediakan struktur di mana selanjutnya Peristiwa dialokasikan nilai berita, melaporkan dan membuat rasa.

Sebagai contoh, kerangka narasi dominan untuk membuat rasa peristiwa dalam Partai Konservatif Inggris menyusul Pemilu 1992 dapat 
dinyatakan dalam hal 'krisis kepemimpinan'. wartawan politik - didorong oleh unsur-unsur Thatcher di Partai Konservatif benci pemecatan mendadak pemimpin mereka dari office - menceritakan kisah terus hentakan John Mayor oleh angin keras kemalangan politik. The 'cerita' dari Partai Buruh selama periode yang sama, di sisi lain, adalah relatif positif salah satu modernisasi dan pembaruan. Ketika pemimpin Partai Buruh John Smith mati mendadak pada tanggal 12 Mei 1994, liputan media dari keberhasilannya dalam mengubah citra partai dan meningkatkan 'keterpilihan' nya adalah seragam positif. Pemilihan Tony Blair sebagai pemimpin Partai Buruh pada tanggal 26 Juli tahun yang berlangsung dalam suasana dukungan euforia kemampuannya, bersama bahkan oleh seperti organ sayap kanan sebelumnya sebagai London Evening Standard. Wartawan juga menghargai New keterampilan tenaga kerja dalam hubungan masyarakat dan manajemen berita, dan tak terkalahkan dari Buruh spin dokter '(lihat Bab 7) menjadi kerangka narasi yang kuat di media membuat rasa transisi tenaga kerja untuk pemerintah pantas dipilih. Konservatif, Sementara itu, didera dari 1994 dan seterusnya tidak hanya dengan memiliki semua yang mereka katakan dan lakukan ditafsirkan sebagai bagian dari kepemimpinan yang sedang berlangsung krisis, tetapi juga oleh narasi mengembangkan kebatilan, yang menambahkan korupsi dan kemunafikan moral untuk partai yang dirasakan masalah. Dari 'krisis kepemimpinan' kerangka dominan untuk membuat rasa Konservatif berkembang menjadi salah satu pembusukan, 
penurunan dan kekalahan dekat. Jadi kuat melakukan kerangka ini menjadi sebagai perangkat penataan jurnalistik bahwa tidak ada partai kepemimpinan bisa lakukan untuk menyoroti kekuatan ekonomi (dan ketika Tories meninggalkan kantor pada tahun 1997 perekonomian sedang melakukan sangat baik oleh standar Inggris) bisa merusak itu.

\section{JURNALIS CENDIKIAWAN DAN JURNALISME POLITIK}

Lembaga media dan orang-orang yang terlibat di dalamnya, media tidak hanyamengirimkan pesan-pesan politik kepada publik, mereka adalah bagian penting dari lingkungan di mana politik sedang berkembang. Mereka berkontribusi diskusi kebijakan dan resolusi, tidak hanya sejauh mereka mengatur masyarakat. Mereka mengubah pesan melalui berbagai proses pembuatan berita. Mereka memasukkan peristiwa kehidupan politik ke dalam kerangka narasi yang memungkinkan mereka untuk dikatakan sebagai berita. Ini kerangka tidak muncul sepenuhnya terbentuk dari pena jurnalistik saja.

Berkembang dari waktu ke waktu dalam interaksi dan kompetisi antara berbagai media berita, antara berbagai aktor, atau sumber, cerita. Kerangka bersaing yang dipersempit dan dieliminasi sampai satu Kerangka dominan tetap. Meskipun selalu tunduk pada tantangan dan revisi, kerangka dominan setelah dibentuk, memberikan struktur di mana peristiwa selanjutnya dialokasikan nilai berita, melaporkan dan membuat rasa. 
Misalnya, peristiwa dalam Partai Konservatif Inggris setelah pemilihan 1992 bisa dinyatakan dalam hal 'krisis kepemimpinan'. Wartawan politik - didorong oleh unsur-unsur Thatcher dalam Partai Konservatif yakni pemberhentian mendadak pemimpinmereka dari kantor menceritakan sebuah kisah John Mayor oleh hentakan angin yang keras dari kemalangan politik. Dari 'cerita' Partai Buruh selama periode yang sama, di sisi lain, adalah relatif positif modernisasi dan pembaruan. Ketika pemimpin Partai Buruh John Smith mati mendadak pada tanggal 12 Mei 1994, media keberhasilannya dalam mengubah gambar partai dan meningkatkan 'keterpilihan' nya adalah seragam positif. Sementara berita sering digunakan dengan cara yang dijelaskan di sini, ada 'menulis' bentuk intervensi politik yang tersedia untuk pers. Itu yang paling penting 'suara' dari surat kabar adalah editorial, yang mewujudkannya identitas politik. Beberapa bentuk jurnalisme politik dikerahkan oleh pers juga digunakan dalam penyiaran, yang juga telah menghasilkan kelas pakar sendiri. Sejajar peran bardic dari Eye Swasta di televisi adalah pertunjukan wayang yang tokoh politik saat ini di istilah yang agak tak di kenal. Satu juga harus mencakup dalam kategori output ini yang jelas tidak menjadi bingung dengan jurnalisme, berusaha untuk mewakili rakyat terhadap pemimpin mereka - impresionis dan penulis komik dengan kandungan politik yang kuat dalam bahan mereka, seperti Rory Bremner dan Chris Morris, dan komedian yang mengkhususkan diri dalam berat dipolitisir stand-up rutinitas. Bergerak lebih dekat ke jurnalisme adalah 
pewawancara, seperti Jon Stewart, yang mempekerjakan format chattingshow, tapi renda dengan unsur satir ejekan dari kuat.

Penyiaran Inggris, seperti yang telah dijelaskan, terikat oleh aturan ketat ketidakberpihakan, yang pasti membatasi sejauh mana wartawan dapat cocok dengan pakar sangat dogmatis pers. Mereka harus dilihat dan mendengar menjadi teliti adil, seimbang dan netral, setidaknya berkaitan dengan politisi konstitusional sistem partai mainstream. Kami sudah mencatat kritik sering terbuat dari siaran berita penyimpangan yang dari ideal 'ketidakberpihakan', dan saran yang pada kenyataannya mengandung mendalam Bias struktural terhadap status quo. Perhatian kita di sini, bagaimanapun, adalah dengan kecenderungan penyiar ', dan tanggung jawab yang dikenakan secara hukum demi kepentingan dari demokrasi yang kuat dan sehat, tidak memihak dalam perselisihan politik. Salah satu ekspresi ketidakberpihakan ini peran lembaga penyiaran 'sebagai pemancar dari wacana politik.Pers dapat melaporkan apa yang seorang politikus mengatakan, tapi penyiar dapat mengirimkan itu hidup, dalam warna. Meskipun kontroversi yang disertai siaran live pertama dari Parlemen, di radio dan kemudian televisi, kini menjadi komponen yang diterima dari politik Inggris Proses (Hetherington 1990 Franklin, 1992). Siaran langsung pada saluran utama tetap dibatasi untuk Perdana Menteri Pertanyaan Waktu dan acara-acara khusus, tetapi secara bertahap diperluas (dibantu oleh Sky News) menjadi berbagai program 'review' 
yang memberikan penampil tertarik dan pendengar gambaran yang lebih besar dari bisnis parlemen.

Meskipun persyaratan ketidakberpihakan dikenakan pada penyiar di ini dan konteks lain, ada beberapa format yang penyiaran wartawan, seperti rekan-rekan pers, dapat melampaui pelaporan hanya politik dan pindah ke peran peserta aktif. Di tingkat yang paling umum, penyiaran bekerja sebagai bagian dari sistem media yang lebih luas untuk menentukan agenda dan 'realitas politik' pada waktu tertentu. Televisi dan radio untuk sebagian besar mengikuti agenda berita ditetapkan oleh pers, satu set makan media dan memperkuat persepsi orang lain tentang apa yang penting. Program berita langsung tidak, untuk alasan yang telah disebutkan, menyimpang jauh melampaui fungsi reportase sempit.

Konteks utama dalam wawancara di mana presenter dapat secara terbuka memainkan peran yang lebih aktif dalam proses politik adalah ketika mereka memiliki kesempatan untuk mewawancarai actor politik. Dalam program siaran berita wawancara politik merupakan salah satu unsur dalam campuran dari reportase, komentar dan analisis. Beberapa wartawan, bagaimanapun memiliki gaya tersendiri dalam membawakan program. Sementara pers sejak awal sebagai kumpulan dasarnya satu perusahaan kapitalis penyiaran telah mengambil berbagai bentuk organisasi. Di Amerika radio dan televisi dikembangkan secara komersial di danai oleh pendapatan iklan. 
Peran demokrasi media akan terpenuhi jika disatu pihak, kepatuhan terhadap etika professional objektivitas dalam melaporkan fakta urusan public. Objektivitas yang tersirat jelas menjauhkan jurnalistik dari pendapat yang diungkapkan dalm debat politik, dengan tekad untuk tidak membingungkan pendapat-pendapat dengan melaporkan fakta.

Dengan demikian, Inggris Broadcasting Corporation (BBC) muncul sebagai public yang menjadi sebagai public yang didanai, tetapi politik independent dilindungi dari campur tangan dalam kegiatan-kegiatannya oleh pemerintahan. Bahkan ketika prinsip-prinsip komersial diizinkan untuk memasuki arena penyiaran inggris dengan pembentukan jaringan independent televisi, BBC ini memiliki 4 saluran (BBC1, BBC2, Newsnight, dan Channel 4)

Proses produksi media adalah salah satu yang dapat di pelajari dan dipahami oleh mereka yang ingin mendapatkan akses menguntungkan. Aktor politik dengan sumber daya terbesar dari dasar untuk mengejar strategi adalah terletak di lembaga-lembaga yang di dirikan kekuasaan seperti organisasi pemerintah dan Negara.

\section{KESIMPULAN}

Peran media sebagai aktor politik dimana media sebagai sumber yang menyampaikan informasi kepada khalayak banyak. Peran media juga bersifat persuasif dimana media bisa mempengaruhi masyarakat. Dalam hal ini, media menjadi alat politik yang digunakan untuk mempengaruhi 
masyarakat demi tujuan politik pihak yang menguasai media tersebut. Adapun wartawan di dalamnya menjadi partisan atau tim sukses politk.

\section{DAFTAR PUSTAKA}

McNair, B, 1995. An Introduction Political Communication: Routledge 